\title{
Dose-dependent effectiveness of ketamine nebulisation in preventing post- operative sore throat due to tracheal intubation
}

\author{
$M \operatorname{Reddy}^{\mathbf{I}^{*}}, \mathbf{S}$ Fiaz $^{2}$ \\ Professor $^{I^{*}}$, Resident $^{2}$, Department of Anesthesiology \\ Kempegowda Institute of Medical Sciences, Bangalore, Karnataka, India.
}

\begin{abstract}
Background: Sore throat is a common and distressing post-operative complication following endotracheal intubation that contributes to patient discomfort. Several pharmacological and nonpharmacological methods may be used to attenuate post-operative sore throat. In literature, there is no study evaluating dose-dependent effectiveness of ketamine nebulisation, neither has there been a study to assess patient acceptability with ketamine nebulisation. The prime objective of this study was to assess graded doses of ketamine nebulization in attenuation of post-operative sore throat and patient acceptability and satisfaction.
\end{abstract}

Materials and Methods: 90 patients between age group of 18 and 60yrs of ASA physical status 1 and 2 of either sex undergoing surgeries in supine position under general anaesthesia lasting for $>$ $1 \mathrm{hr}$, were randomly allocated into three groups. Group A received $0.5 \mathrm{mg} / \mathrm{kg}$, group B received $1 \mathrm{mg} / \mathrm{kg}$ and group $\mathrm{C}$ received $1.5 \mathrm{mg} / \mathrm{kg}$ body weight of nebulized preservative free ketamine for $15 \mathrm{mins}, 5 \mathrm{mins}$ before intubation. The patients were then assessed for acceptability to ketamine nebulization. At the end of the surgery post-operative sore throat was assessed at $0,2,4,6,8,12$ and $24 \mathrm{hrs}$.

Results: Nebulized ketamine at a dose of $0.5 \mathrm{mg} / \mathrm{kg}$ was comparatively less effective than $1 \mathrm{mg} / \mathrm{kg}$ and $1.5 \mathrm{mg} / \mathrm{kg}$ and the difference was statistically significant. $1 \mathrm{mg} / \mathrm{kg}$ and $1.5 \mathrm{mg} / \mathrm{kg}$ of nebulized ketamine are better and equally effective in reducing the incidence and severity of post-operative sore throat. There was no statistical difference in the acceptability scores to the different doses of nebulised ketamine.

Conclusion: Nebulized ketamine is well accepted by all patients and effective in reducing the severity of post-operative sore throat without any untoward effects. However larger population studies and estimation of serum ketamine levels is needed to find out a better dose of ketamine for nebulization to prevent the incidence and severity of post-operative sore throat.

Keywords: ketamine; nebulisation; post-operative sore-throat; dose-dependent

\section{Introduction}

Sore throat is a common post-operative complication following endotracheal intubation during general anaesthesia.

*Correspondence: M Reddy

E mail: madhavareddy.r@gmail.com

iD https://orcid.org/0000-0002-2288-8165

Received: $10 / 07 / 2017$

Accepted: 16/10/2017

DOI: http://doi.org/10.4038/slja.v26i1.8264

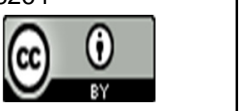

Although post-operative sore throat is a selflimiting condition, it contributes to patient discomfort. The incidence of post-operative sore throat varies from 21 to $66 \%{ }^{1}$

Localised trauma to the mucosa during laryngoscopy and intubation leads to aseptic inflammation of the pharyngeal mucosa leading to post-operative sore throat. ${ }^{2}$

Many non-pharmacological and pharmacological methods have been tried to reduce the incidence

and severity of post-operative sore throat. Using a small sized endotracheal tube, gentle laryngoscopy and intubation, maintaining cuff pressures not more 
than $18-20 \mathrm{cmH}_{2} \mathrm{O}$, and local anaesthetics, steroids, NSAIDs, benzydamine gargle, ketamine gargle are some of the methods used by different authors with variable success. ${ }^{2,3}$

Ketamine, a phencyclidine derivative, has been used as a gargle or nebulization in the attenuation of post-operative sore throat by its action on peripheral NMDA receptors. ${ }^{4,5,6}$ In gargle form a large volume of the drug is used, hence patients are at risk of aspiration and it is difficult to perform. These complications can be avoided by using nebulized ketamine. A fixed dose of ketamine nebulisation $50 \mathrm{mg}$ in $5 \mathrm{ml}$ saline has been used in prevention of post-operative sore throat. ${ }^{2,7,8}$

In literature, there are no studies evaluating dosedependent effectiveness of ketamine nebulisation, nor patient acceptability with ketamine nebulisation. The prime objective of this study was to assess graded doses of ketamine nebulization in attenuation of post-operative sore throat and patient acceptability and satisfaction.

Hence, we compared $0.5 \mathrm{mg} / \mathrm{kg}, 1 \mathrm{mg} / \mathrm{kg}$ and $1.5 \mathrm{mg} / \mathrm{kg}$ dose of ketamine nebulisation in reducing the severity and incidence of post-operative sore throat.

\section{Material and methods}

After obtaining approval from the Institutional Ethics Committee, written informed consent was taken from 90 patients between age group of 18 and $60 \mathrm{yrs}$ of ASA physical status 1 and 2 of either sex undergoing surgeries in supine position under general anaesthesia lasting for more than one hour. Patients who were enrolled in the study were explained about the post-operative assessment of sore throat.

Patients with Mallampati class $>2$, pre-operative sore throat, allergy to study drug, recent history of NSAID medication, smokers, asthmatics, patients with COPD, weight $>80 \mathrm{kgs}$, head and neck surgeries, those who require more than two attempts at intubation, surgeries requiring nasogastric tube and throat pack insertion were excluded from the study. Patients in whom extubation caused coughing or bucking were also excluded from the study.
Presuming the incidence of post-operative sore throat to be $65 \%$, the power analysis (taking $\alpha=0.05$ and $\beta=0.90$ ) calculated a sample size of 22 patients in each of the three groups to show a 50\% reduction in the incidence. We chose to enroll 30 patients in each group.

Patients were randomly allocated into three groups of 30 patients each by a computer generated closed envelope technique in opaque sealed envelopes prepared by ananaesthesiologist not part of the study. The envelopes were opened by the resident, and nebulisation solution was prepared according to group allocation. Group A received $0.5 \mathrm{mg} / \mathrm{kg}$, group $B$ received $1 \mathrm{mg} / \mathrm{kg}$ and group $\mathrm{C}$ received $1.5 \mathrm{mg} / \mathrm{kg}$ body weight of nebulized preservative free ketamine (Aneket 50mg/ml, 2ml ampoule, Neon Laboratories Ltd,).

Baseline vital parameters were recorded. The study drug was diluted to $5 \mathrm{ml}$ and administered for 15 mins through a compressed nebulizer. The resident later did not participate in the subsequent assessment of these patients. Patients were blinded as all the three solutions tasted the same.

Patients were assessed for the acceptability and satisfaction to ketamine nebulisation with acceptability score (Score 0 -Acceptable, Score 1Not Acceptable due to either nebulisation or taste of the drug, Score 2 - Not Acceptable due to both nebulisation and taste).

Acceptability is defined as patients performing nebulization without any difficulty considered as acceptable and given a score of 0 . If the patients complain of either bitter taste of the drug or difficulty in performing nebulization, were given a score of 1. Patients complaining of both bitter taste of the drug and difficulty in performing nebulization were given a score of 2 .

Five minutes after nebulization patients were premedicated with glycopyrrolate $0.005 \mathrm{mg} / \mathrm{kg}$, midazolam $0.02 \mathrm{mg} / \mathrm{kg}$, ondansetron $4 \mathrm{mg}$ i.v. Fentanyl $2 \mathrm{mcg} / \mathrm{kg}$ was given as an analgesic followed by induction with propofol $2 \mathrm{mg} / \mathrm{kg}$ and intubation was facilitated with vecuronium $0.1 \mathrm{mg} / \mathrm{kg}$ i.v. Lignocaine $2 \%$ (preservative free) $1 \mathrm{mg} / \mathrm{kg}$ was given i.v. 90secs before tracheal intubation. 
Trachea was intubated with a sterile polyvinyl chloride cuffed endotracheal tube with an internal diameter of 7 to $7.5 \mathrm{~mm}$ for female and 8 to $8.5 \mathrm{~mm}$ for male patients. The cuff was inflated till no air leakage could be heard by auscultation over trachea and cuff pressure was maintained between 18 to $20 \mathrm{~cm} \mathrm{H}_{2} \mathrm{O}$ measured by a handheld manometer. Anaesthesia was maintained with oxygen, nitrous oxide and isoflurane.

Residual neuromuscular blockade was reversed with intravenous neostigmine $0.05 \mathrm{mcg} / \mathrm{kg}$ and glycopyrrolate $0.01 \mathrm{mg} / \mathrm{kg}$. Lignocaine $2 \%$ (preservative free) $1 \mathrm{mg} / \mathrm{kg}$ was given 90 secs before extubation. Then the patient was extubated gently following suction under direct laryngoscopic vision, and once awake the patient was assessed for post-operative sore throat which was taken as 0 hours. This was followed by further assessments at $2,4,6,8,12$ and $24 \mathrm{hrs}$ on a four-point scale. . $^{27,8,12}$

0- No Sore Throat

1- Mild discomfort, mild sore throat (complains of sore throat only on asking)

2 - Moderate sore throat (complains of sore throat on his or her own)

3- Severe sore throat (associated with pain, change of voice or hoarseness)

In between the assessment time intervals if the patients complain of sore throat, pain or hoarseness of voice on their own it was considered as score 2 or 3 that is moderate or severe sore throat depending upon the severity.

Post-operative pain was managed with tramadol 50 mg i.v. 8hrly. For patients with severe sore throat rescue analgesia was given with paracetamol $1 \mathrm{gm}$ i.v. Patients were monitored for adverse effects such as nausea, vomiting, cough and dryness of mouth and treated accordingly.

\section{Results}

Of the 90 patients screened in our study, 9 patients were excluded from group A, B and C. Coughing and bucking was observed in 5 patients ( 2 in group A, 1 in group B and 2 in group C), 4 patients required more than 2 attempts for intubation (1 each in group $\mathrm{A}$ and $\mathrm{C}$ and 2 patients in group $\mathrm{B}$ ).

The distribution of gender, ETT size $(\mathrm{P}=0.728$, ANOVA test) in the three study groups was statistically not significant. Weight distribution in group A, B and $\mathrm{C}$ was $55.33 \pm 5.86,58.22 \pm 4.32$ and $54.52 \pm 4.16 \mathrm{~kg}$ respectively $(\mathrm{P}=0.016)$ by ANOVA test. (Table 1)

Table 1: Demographic data, ETT size distribution and duration of surgery in three groups

\begin{tabular}{|c|c|c|c|c|c|}
\hline Groups & $\begin{array}{l}\text { Group } \\
\text { A } \\
(\mathbf{n}=27)\end{array}$ & $\begin{array}{l}\text { Group } \\
\text { B } \\
(n=27)\end{array}$ & $\begin{array}{l}\text { Group C } \\
(\mathbf{n}=27)\end{array}$ & $\begin{array}{l}P \\
\text { value }\end{array}$ & $\begin{array}{l}\text { Statistical } \\
\text { analysis }\end{array}$ \\
\hline Age (in years) & $\begin{array}{l}32.89 \pm 1 \\
0.35 \\
\end{array}$ & $\begin{array}{l}40.15 \pm 7 \\
.06\end{array}$ & $\begin{array}{l}36.74 \pm 9.2 \\
3\end{array}$ & 0.015 & ANOVA test \\
\hline Gender (F:M) & $17: 10$ & $16: 11$ & $17: 10$ & 0.949 & Chi-Square test \\
\hline Weight $(\mathrm{kg})$ & $\begin{array}{l}55.33 \pm 5 \\
.86 \\
\end{array}$ & $\begin{array}{l}58.22 \pm 4 \\
.32 \\
\end{array}$ & $\begin{array}{l}54.52 \pm 4.1 \\
6\end{array}$ & 0.016 & ANOVA test \\
\hline ET tube size & $\begin{array}{l}7.61 \pm \\
0.56 \\
\end{array}$ & $\begin{array}{l}7.72 \pm \\
0.53 \\
\end{array}$ & $\begin{array}{l}7.70 \pm 0 . \\
56\end{array}$ & $\begin{array}{l}0.72 \\
8 \\
\end{array}$ & $\begin{array}{l}\text { ANOVA } \\
\text { test }\end{array}$ \\
\hline $\begin{array}{l}\text { Duration of } \\
\text { surgery }\end{array}$ & $\begin{array}{l}137.1 \\
9 \pm 35 \\
09\end{array}$ & $\begin{array}{l}121.3 \\
0 \pm 29 \\
50\end{array}$ & $\begin{array}{l}120.19 \\
\pm 28.81\end{array}$ & $\begin{array}{l}0.08 \\
9\end{array}$ & $\begin{array}{l}\text { ANOVA } \\
\text { test }\end{array}$ \\
\hline
\end{tabular}

Average dose distribution in three groups of patients studied was $27.89 \pm 2.86,58.22 \pm 4.32$ and $82.04 \pm 6.18$ respectively $(\mathrm{P}<0.001$, significant, ANOVA test).

All patients in group $\mathrm{A}, \mathrm{B}$ and $\mathrm{C}$ were acceptable to ketamine nebulization (acceptability score 0 ). None of the patients in any study group had an acceptability score of 1 and 2. Acceptability Score distribution in three groups of patients studied is not significant by Fisher Exact test $(\mathrm{P}=1.000)$.

Table 2: Acceptability score distribution in three groups of patients studied

\begin{tabular}{|l|l|l|l|l|}
\hline $\begin{array}{l}\text { Acceptability } \\
\text { Score }\end{array}$ & Group A & Group B & Group C & Total \\
\hline Acceptable & $27(100 \%)$ & $27(100 \%)$ & $27(100 \%)$ & $81(100 \%)$ \\
\hline $\begin{array}{l}\text { Discomfort } \\
\text { due to } \\
\text { nebulisation } \\
\text { or taste of the } \\
\text { drug }\end{array}$ & $0(0 \%)$ & $0(0 \%)$ & $0(0 \%)$ & $0(0 \%)$ \\
\hline $\begin{array}{l}\text { Discomfort } \\
\text { due to both } \\
\text { taste and } \\
\text { nebulization }\end{array}$ & $0(0 \%)$ & $0(0 \%)$ & $0(0 \%)$ & $0(0 \%)$ \\
\hline \begin{tabular}{l} 
Total \\
\hline
\end{tabular} & $27(100 \%)$ & $27(100 \%)$ & $27(100 \%)$ & $81(100 \%)$ \\
\hline
\end{tabular}


Table 3: Sore throat score distribution in three groups (Chi-Square test/Fisher Exact test)

\begin{tabular}{|c|c|c|c|c|c|c|c|}
\hline $\begin{array}{l}\text { Sore } \\
\text { Throat } \\
\text { Score }\end{array}$ & 0 & $2 \mathrm{hr}$ & 4hrs & 6hrs & 8hrs & 12hrs & 24hrs \\
\hline \multicolumn{8}{|l|}{$\begin{array}{l}\text { Group } \\
\text { A } \\
(n=27)\end{array}$} \\
\hline No & $\begin{array}{l}10 \\
(37 \% \\
)\end{array}$ & $\begin{array}{l}8 \\
(29.6)\end{array}$ & $\begin{array}{l}7 \\
(25.9)\end{array}$ & $\begin{array}{l}8 \\
(29.6)\end{array}$ & $\begin{array}{l}11 \\
(40.7)\end{array}$ & $\begin{array}{l}12 \\
(44.4 \%)\end{array}$ & $\begin{array}{l}12 \\
(44.4 \\
\%)\end{array}$ \\
\hline Mild & $\begin{array}{l}14 \\
(51.9 \\
\%)\end{array}$ & $\begin{array}{l}16 \\
(59.3 \\
\%)\end{array}$ & $\begin{array}{l}19 \\
(70.4 \\
\%)\end{array}$ & $\begin{array}{l}18 \\
(66.7 \\
\%)\end{array}$ & $\begin{array}{l}16 \\
(59.3 \% \\
)\end{array}$ & $\begin{array}{l}15 \\
(55.6 \%)\end{array}$ & $\begin{array}{l}15 \\
(55.6 \\
\%)\end{array}$ \\
\hline $\begin{array}{l}\text { Modera } \\
\text { te }\end{array}$ & $\begin{array}{l}3 \\
(11.1 \\
\%)\end{array}$ & $\begin{array}{l}3 \\
(11.1 \\
\%)\end{array}$ & $\begin{array}{l}1 \\
(3.7 \%)\end{array}$ & $\begin{array}{l}1 \\
(3.7 \%)\end{array}$ & $0(0 \%)$ & $0(0 \%)$ & $0(0 \%)$ \\
\hline Severe & $\begin{array}{l}0(0 \% \\
)\end{array}$ & $0(0 \%)$ & $0(0 \%)$ & $0(0 \%)$ & $0(0 \%)$ & $0(0 \%)$ & $0(0 \%)$ \\
\hline \multicolumn{8}{|l|}{$\begin{array}{l}\text { Group } \\
\text { B } \\
(\mathrm{n}=27) \\
\end{array}$} \\
\hline $\mathbf{0}$ & $\begin{array}{l}21(77 \\
.8 \%)\end{array}$ & $\begin{array}{l}12(44 . \\
4 \%)\end{array}$ & $\begin{array}{l}7(25.9 \\
\%)\end{array}$ & $\begin{array}{l}7(25.9 \\
\%)\end{array}$ & $\begin{array}{l}11(40.7 \\
\%)\end{array}$ & $\begin{array}{l}19(70.4 \\
\%)\end{array}$ & $\begin{array}{l}19(70 . \\
4 \%)\end{array}$ \\
\hline 1 & $\begin{array}{l}6(22 . \\
2 \%)\end{array}$ & $\begin{array}{l}15(55 . \\
6 \%)\end{array}$ & $\begin{array}{l}19(70 . \\
4 \%)\end{array}$ & $\begin{array}{l}20(74 . \\
1 \%)\end{array}$ & $\begin{array}{l}16(59.3 \\
\%)\end{array}$ & $\begin{array}{l}8(29.6 \% \\
)\end{array}$ & $\begin{array}{l}8(29.6 \\
\%)\end{array}$ \\
\hline 2 & $0(0 \%$ & $0(0 \%)$ & $\begin{array}{l}1(3.7 \\
\%)\end{array}$ & $0(0 \%)$ & $0(0 \%)$ & $0(0 \%)$ & $0(0 \%)$ \\
\hline 3 & $\begin{array}{l}0(0.0 \\
\%)\end{array}$ & $\begin{array}{l}0(0.0 \\
\%)\end{array}$ & $\begin{array}{l}0(0.0 \\
\%)\end{array}$ & $\begin{array}{l}0(0.0 \\
\%)\end{array}$ & $\begin{array}{l}0(0.0 \% \\
)\end{array}$ & $0(0.0 \%)$ & $\begin{array}{l}0(0.0 \\
\%)\end{array}$ \\
\hline \multicolumn{8}{|l|}{$\begin{array}{l}\text { Group } \\
\text { C } \\
(\mathrm{n}=27)\end{array}$} \\
\hline 0 & $\begin{array}{l}23(85 \\
.2 \%)\end{array}$ & $\begin{array}{l}16(59 . \\
3 \%)\end{array}$ & $\begin{array}{l}12(44 . \\
4 \%)\end{array}$ & $\begin{array}{l}14(51 . \\
9 \%)\end{array}$ & $\begin{array}{l}19(70.4 \\
\%)\end{array}$ & $\begin{array}{l}21(77.8 \\
\%)\end{array}$ & $\begin{array}{l}21(77 . \\
8 \%)\end{array}$ \\
\hline 1 & $\begin{array}{l}4(14 . \\
8 \%)\end{array}$ & $\begin{array}{l}11(40 . \\
7 \%)\end{array}$ & $\begin{array}{l}15(55 . \\
6 \%)\end{array}$ & $\begin{array}{l}13(48 . \\
1 \%)\end{array}$ & $\begin{array}{l}8(29.6 \\
\%)\end{array}$ & $\begin{array}{l}6(22.2 \% \\
)\end{array}$ & $\begin{array}{l}6(22.2 \\
\%)\end{array}$ \\
\hline 2 & $\begin{array}{l}0(0 \% \\
)\end{array}$ & $0(0 \%)$ & $0(0 \%)$ & $0(0 \%)$ & $0(0 \%)$ & $0(0 \%)$ & $0(0 \%)$ \\
\hline 3 & $\begin{array}{l}0(0.0 \\
\%)\end{array}$ & $\begin{array}{l}0(0.0 \\
\%)\end{array}$ & $\begin{array}{l}0(0.0 \\
\%)\end{array}$ & $\begin{array}{l}0(0.0 \\
\%)\end{array}$ & $\begin{array}{l}0(0.0 \% \\
)\end{array}$ & $0(0.0 \%)$ & $\begin{array}{l}0(0.0 \\
\%)\end{array}$ \\
\hline$P$ value & $\begin{array}{l}<0.00 \\
1\end{array}$ & 0.062 & 0.435 & 0.120 & 0.047 & 0.032 & 0.032 \\
\hline
\end{tabular}

At $0 \mathrm{hrs}, 37 \%, 77.8 \%$ and $85.2 \%$ patients did not have post-operative sore throat in group $\mathrm{A}, \mathrm{B}$ and $\mathrm{C}$ respectively and the difference was statistically significant ( $\mathrm{P}$ value $<0.001)$.

At 4 hrs, 7 patients $(25.9 \%)$ had no sore throat, 19 patients $(70.4 \%)$ had mild sore throat and 1 patient (3.7\%) had moderate sore throat in both groups A and B; while in group $\mathrm{C} 12$ patients $(44.4 \%)$ had no sore throat, 15 patients $(55.6 \%)$ had mild sore throat and none of the patients had severe sore throat.

At 12 and 24hrs not much difference was found in number of patients having post-operative sore throat in group B and C. 19 patients $(70.4 \%)$ in group B and 21 patients (77.8\%) in group C had no sore throat respectively. 8 patients $(29.6 \%)$ and 6 patients $(22.2 \%)$ had mild sore throat in group B and $\mathrm{C}$ respectively ( $\mathrm{P}$ value 0.032 ). In group $\mathrm{A}, 12$ patients $(44.4 \%)$ had no sore throat and 15 patients $(55.6 \%)$ had mild sore throat. (Table 3 )

Except for thickened secretions in a few patients during extubation in group $\mathrm{C}$ no other untoward events were noted in all the study groups.

\section{Discussion}

Post-operative sore throat is a simple yet distressing complaint in several patients following endotracheal intubation. Ketamine decreases postoperative sore throat by its topical action on peripheral NMDA receptors as an antiinflammatory and anti-nociceptive substance. ${ }^{5,6,9}$ Magnesium, an NMDA receptor antagonist has also been used prophylactically in prevention of postoperative sore throat. ${ }^{10,11}$

In our study, there was no statistically significant difference in the distribution of age, gender, ET tube size and duration of surgery.

Chan, Rudra et al, Canbay et al, have observed that ketamine gargle is effective in attenuation of postoperative sore throat, however it is known to have a bitter taste and patients are at a risk for aspiration due to large volume of the drug., ${ }^{2,7}$ In contrast to this, Ahuja in her study stated that nebulised preservative free ketamine was tasteless ${ }^{12}$ which is in concurrence with our study. All the patients were comfortable with nebulization as the volume of the drug is less and easy to be administered. Nebulized ketamine is safer and easier to administer with better patient compliance.

Pneumatic nebulization produces large sized particles which get deposited in the mouth, throat during the process of nebulization hence reducing the incidence and severity of post-operative sore throat.

According to literature, all other studies have used a fixed dose of $50 \mathrm{mg}$ ketamine nebulization irrespective of patient body weight. Hence, we conducted a study to evaluate dose dependent effectiveness of ketamine nebulization in attenuation of post-operative sore throat and to 
assess patient satisfaction and acceptability with ketamine nebulization.

In our study, at 0 hrs $51.9 \%$ patients had mild sore throat and $11.1 \%$ patients had moderate sore throat in group A, while only $22.2 \%$ patients in group B and $14.8 \%$ patients in group $\mathrm{C}$ had mild sore throat. This difference was found to be statistically significant among the three study groups ( $\mathrm{P}$ value $<0.001)$. However, none of the patients in the three study groups experienced severe sore throat.

Monroe MC et al ${ }^{13}$ showed post-operative sore throat is found to be peak at 2 to $4 \mathrm{hrs}$. By this time the patients are completely conscious and more cooperative to participate in the study. In our study, we have observed maximum incidence of sore throat in group A at $4 \mathrm{hrs}(70.4 \%)$. Incidence of mild sore throat in group B and C at 4 hs was $70.4 \%$ and $55.6 \%$ respectively. There is a gradual decrease in the incidence of sore throat at subsequent time intervals.

The incidence of mild sore throat at $24 \mathrm{hrs}$ was found to be $55.6 \%$ in group A, $29.6 \%$ in group B and $22.2 \%$ in group C. On comparing group $\mathrm{A}$ and $\mathrm{B}$ we observed that when the dose of ketamine is doubled the incidence of sore throat is almost halved.

Though the results in group $\mathrm{C}$ are better compared to group A and B at $0,2,4,6$ and $8 \mathrm{hrs}$, the number of patients having no sore throat and mild sore throat in group B and C are comparable at 12 and $24 \mathrm{hrs}$. Our results are comparable to a study by Jain et al in their nebulization group at 8 and $24 \mathrm{hrs} .{ }^{14}$

A study by Amingad, has shown fewer patients having no sore throat at 0 and $24 \mathrm{hrs}$ as compared to our study which could be attributed to the usage of $2 \%$ lignocaine local anaesthetic jelly applied over the endotracheal tube cuff and intra-operative i.v. dexamethasone used in their nebulized ketamine group. ${ }^{15}$

Throughout the study period we found moderate sore throat in group A till 6hrs only and one patient had moderate sore throat in group B at 4 hrs whereas no patients had moderate or severe sore throat in group C. Increasing doses of ketamine has shown to decrease both incidence and severity of sore throat.

None of the patients in the three study groups experienced severe sore throat at all time intervals hence no patients received paracetamol as rescue analgesia. This rescue analgesia will not affect subsequent assessment of sore throat because a study by Mishra $\mathrm{J}$ et $\mathrm{al}^{16}$ has shown that intravenous paracetamol decreased incidence of sore throat for up to $2 \mathrm{hrs}$ only.

We noted that there were increased and thicker secretions in patients who received $1.5 \mathrm{mg} / \mathrm{kg}$ dose of ketamine nebulization in our study. We have not measured the serum levels of ketamine and its metabolite norketamine to rule out systemic effects of the same.

\section{Conclusion}

Nebulized ketamine is well accepted by all patients and effective in reducing the severity of postoperative sore throat without any untoward effects. Nebulized ketamine at a dose of $0.5 \mathrm{mg} / \mathrm{kg}$ was comparatively less effective than $1 \mathrm{mg} / \mathrm{kg}$ and $1.5 \mathrm{mg} / \mathrm{kg}$ and the difference was statistically significant. $1 \mathrm{mg}$ and $1.5 \mathrm{mg} / \mathrm{kg}$ dose did not show much difference except increased and thickened secretions in $1.5 \mathrm{mg} / \mathrm{kg}$ group. $1 \mathrm{mg} / \mathrm{kg}$ and $1.5 \mathrm{mg} / \mathrm{kg}$ of nebulized ketamine are better and equally effective in reducing the incidence and severity of post-operative sore throat. However larger population studies and estimation of serum ketamine levels is needed to find out a better dose of ketamine for nebulization to prevent the incidence and severity of post-operative sore throat.

\section{Conflicts of interest}

There are no conflicts of interest

\section{References:}

1. Huang YS, Hung NK, Lee MS, et al. The effectiveness of benzydamine hydrochloride spraying on the endotracheal tube cuff or oral mucosa for postoperative sore throat. Anesth Analg. 2010;111(4):887-891

https://doi.org/10.1213/ANE.0b013e3181e6d82a

2. Canbay O, Celebi N, Sahin A, Celiker V, Ozgen S, Aypar U. Ketamine gargle for attenuating postoperative sore throat. British Journal of Anaesthesia 2008; 100(4): 490-493. 
https://doi.org/10.1093/bja/aen023

PMid:18310675

3. Kalil DM, Silvestro LS, Austin PN. Novel preoperative pharmacologic methods of preventing postoperative sore throat due to tracheal intubation. AANA Journal 2014;82(3):188-197 PMid:25109156

4. Patel MP, Patel HH, Roth DM. general anesthetics and therapeutic gases. In: Goodman and Gilman's The pharmacological basis of therapeutics. 12th edition. Edited by Brunton LL, Chabner BA, Knollman BC 2011; chapter 19: 502-539

5. Stoelting RK, Hillier SC. Intravenous sedatives and hypnotics, In: Pharmacology and Physiology in Anaesthetic Practice. 5th edition. Edited by Stoelting RK, Hillier SC 2014; chapter 5: 186-93.

6. Vuyk J, Sitsen E, Reekers M. Intravenous anesthetics. In: Miller's Anesthesia. 8th ed. Edited by Miller RD, Eriksson LI, Fleisher LA:Philadelphia, Elsevier. 2015, 845-848.

7. Chan L, Lee ML, Lo YL. Postoperative sore throat and ketamine gargle. British Journal of Anaesthesia 2010;105:97

https://doi.org/10.1093/bja/aeq152

PMid:20551036

8. Rudra A, Ray S, Chatterjee S, Ahmed A, Ghosh S. Gargling with ketamine attenuates the postoperative sore throat. Indian Journal of Anaesthesia 2009;53(1):40-43.

PMid:20640076 PMCid:PMC2900032

9. Patel MP, Patel HH, Roth DM. general anesthetics and therapeutic gases. In: Goodman and Gilman's The pharmacological basis of therapeutics. 12th edition. Edited by Brunton LL, Chabner BA, Knollman BC 2011; chapter 19: 502-539

10. Gupta SK, Tharwani S, Singh DK, Yadav G. Nebulised magnesium for prevention of postoperative sore throat. Br. J. Anaesth 2012; 108: 168-169

https://doi.org/10.1093/bja/aer437

PMid:22157461

11. Gupta DI, Agrawal SA, Sharma JP. Effect of preoperative licorice lozenges on incidence of postextubation cough and sore throat in smokers undergoing general anesthesia and endotracheal intubation. Middle East J Anaesthesiol. 2013;22:173-8.

PMid:24180166

12. Ahuja V, Mitra S, Sarna R. Nebulized ketamine decreases incidence and severity of post-operative sore throat. Indian journal of anaesthesia 2015; 59(1): 37-42.

https://doi.org/10.4103/0019-5049.149448

PMid:25684812 PMCid:PMC4322100
13. Monroe M C, Gravenstein N, Saga - Rumley S. Post airway in orotracheally intubated patients. Anesth Analg 1990;70:512 -6. PMid:2331067

14. Jain S, Bendwal HP, Gohiya S, Alwani N, Pancholi S, Romday R. Comparison of nebulized ketamine and ketamine with clonidine in postoperative sore throat. International Surgery Journal. 2017;4(5):1579-83. https://doi.org/10.18203/2349-2902.isj20171515

15. Amingad B, Jayaram S. Comparison of ketamine nebulisation with ketamine gargle in attenuating post-operative sore throat. Indian Journal of Clinical Anaesthesia. 2016;3(3):347-51. https://doi.org/10.5958/2394-4994.2016.00060.3

16. Mishra J, Nanda S, Dalai H, et al. Paracetamol in prevention of postoperative sore throat- an observational study. J. Evid. Based Med. Healthc. 2017; 4(57), 3434-3437. DOI: $10.18410 /$ jebmh/2017/684. https://doi.org/10.18410/jebmh/2017/684 